\title{
НЕФОРМАЛЬНА ТА ІНФОРМАЛЬНА ОСВІТА ХОРЕОГРАФІВ В УКРӒ̈НI
}

\author{
Разуменко Т. О. \\ кандидат педагогічних наук, доцент, доцент кафедри англійської мови, \\ Харківський національний педагогічний університет імені Г. С.Сковороди, \\ м. Харків, Україна
}

У статті розглядаються поняття освіти протягом життя, неформальної та інформальної освіти, особливості освіти протягом

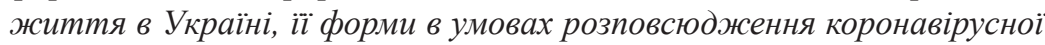
інфекиії, формати розбудови: «вбудовуватися» в систему формальної, доповнювати ї̈ або бути провідником змін для неї.

Ключові слова: хореографія, танець,неформальна освіта, інформальна освіта.

The article considers the concepts of lifelong learning, non-formal and informal education, features of lifelong learning in Ukraine, its forms in the context of coronavirus pandemic, development formats: "embedded» in the system of formal education, complete it or be a driver of changes for it.

Key words: choreography, dance, non-formal education, informal education

У кінці XIX ст. на Заході заговорили про неформальну та інформальну освіту. Існувало дві основні концепції: американська і європейська. Інфраструктура неформальної та інформальної освіти США була створена у 1990-2000-і роки, європейська - у 2000-і, коли стало очевидно, що здобути всі необхідні знання лише в системі офіційної освіти неможливо. На зміну застарілій концепції «одна освіта на все життя» прийшла нова — «навчання впродовж усього життя» (lifelong education). [1]. Лісабонський саміт Ради Свропи у березні 2000 року прийняв «Меморандум освіти протягом життя» [2].

Освіта протягом життя в усьому світі стає усе більш важливою сферою освітніх послуг. Ця освіта поділяється на формальну, неформальну та інформальну.

Формальна освіта - початкова, загальна середня освіта, середня професійна освіта, вища освіта, освіта після закінчення ЗВО (аспірантура й докторантура), підвищення кваліфікації й перепідготовка фахівців і керівників з вищою і середньою професійною освітою в інсти- 
тутах, на факультетах і курсах підвищення кваліфікації й професійної перепідготовки. [3]. Після закінчення навчання надаються «освітні кваліфікації» — посвідчення, атестати, сертифікати, дипломи, титули. Вони засвідчують здобуття певного рівня знань, умінь, навичок, підтверджених оцінкою, що присуджується за загальноприйнятими критеріями.

Неформальна освіта — це освіта, що необов'язково має організований та систематичний характер. Вона може здійснюватися поза межами організованих освітніх закладів. До сфери неформальної освіти належать індивідуальні заняття під керівництвом тренерів чи репетиторів, тренінги та короткотермінові курси. Неформальна освіта не має вікових, професійних чи інтелектуальних обмежень щодо учасників, нерідко не обмежується часовими рамками. Заклади чи організації, що займаються неформальною освітою, не присуджують кваліфікацій. Під час цієї освіти найчастіше застосовуються інноваційні підходи, апробуються новаторські методики та технології навчання [3].

Інформальна освіта - загальний термін для освіти за межами стандартного освітнього середовища. Це індивідуальна діяльність, що супроводжує повсякденне життя. Вона реалізується завдяки власній активності людини в оточуючому культурно-освітньому середовищі через спілкування, читання, відвідування установ культури, подорожі, засоби масової інформації тощо [3].

Зближення та взаємодоповнення формальної та неформальної освіти, а не конкуренція між ними - загальносвітова тенденція сьогодення.

У країнах СС неформальна освіта сприймається роботодавцями на рівні з формальною. Її розвитку там сприяють міжнародні організації - ООН, ЮНЕСКО, Свропейський Союз, Рада Європи та інші. У Великій Британії, наприклад, вважають, що неформальна освіта - це процес, а не результат. Це скоріше одна зі складових повноцінного життя. [4].

У Франції неформальну дозвільно-орієнтовану освіту дітей і дорослих найчастіше організовують освітні асоціації за підтримки мерій у гуртках, на курсах, під час стажувань, інтенсивів тощо. Здебільшого державні освітні інституції або самі надають допомогу неформальній освіті , або в той чи інший спосіб упливають на цей процес. Нефор- 
мальна освіта, так би мовити, «вбудовується» в систему формальної, доповнюючи іiі та співпрацюючи з нею [4].

В Україні поки що не існує визнаних стандартів неформальної освіти, але є декілька організацій, які займаються розвитком їі стандартів та показників якості; це Українська Академія Лідерства, Prometheus, Міжнаціональний центр неформальної освіти тощо [4]. В Україні неформальна освіта охоплює позашкільну освіту; післядипломну освіту та освіту дорослих; громадянськау освіту; шкільне та студентське самоврядування); освітні ініціативи, спрямовані на розвиток додаткових умінь та навичок (комп'ютерні та мовні курси, гуртки за інтересами тощо [4].

Професія хореографа - досить широке поняття, це може бути й танцівник у складі танцювального колективу, і постановник танців, і керівник дитячого або професійного колективу, і балетмейстер, постановник балетних спектаклів. Професійний хореограф поєднує у своїй роботі функції педагога, репетитора й балетмейстера. [5]. Він повинен мати чудову фізичну форму, хореографічну підготовку, бути прекрасним організатором , артистичним, комунікабельним, обов'язково знатися на теорії та історії музики, сценографії та костюму, питаннях педагогіки, фізіології, психології та анатомії, володіти методикою викладання хореографічних дисциплін, методикою роботи з хореографічним колективом. Всі ці навички та знання хореограф здобуває під час отримання формальної освіти. Але справжній професіонал повинен вміти будувати індивідуальну освітню траєкторію, бути готовим до самоосвіти й саморозвитку [5].

Дитячі хореографічні студії, гуртки народного та бального танцю в Україні надзвичайно популярні в останні десятиліття. Заняття танцями допомагають у фізичному, розумовому та моральному вихованні дітей. Танцювальні ж гуртки для дорослих до останнього часу були не таким поширеним явищем. 32008 року, коли в класифікації сучасної хореографії було визначено місце соціальному танцю (аргентинське танго, вальс, кантрі, свінг, сальса, оріенталь, меренге, мамбо, ламбада, бачата, кізомба), популярність танцювальних студій для дорослих значно зросла. Вони орієнтуються переважно на дозвіллєву діяльність різних вікових категорій (від підлітків до людей зрілого та похилого віку) й гарного прове- 
дення вільного часу або професійних змагань. Соціальні танці засновані на активному контакті між людьми, для яких танець стає формою спілкування. Основними функціями соціального танцю можна вважати: комунікативну, самоідентифікаційну, експресивну, катарсичну, гедоністичну, оздоровчу, рекреаційну та реабілітаційну. Сьогодні в Україні у зв'язку із соціально-політичною напругою та воєнними діями серед основних функцій соціального танцю набуває ваги його реабілітаційна функція [6].

На допомогу українському хореографу в підвищенні професіоналізму та подоланні нових викликів часу повинна прийти неформальна та інформальна освіта. Наприклад, «Харківська обласна громадська організація латиноамериканського танцю» неодноразово проводила конгрес викладачів по методиці викладання кубінської сальси та кубінської румби за участі інструкторів міжнародного класуАльберта Вальдеса та Андреа Панагі (2013), Хорхе Камагвея (2016), Хуана Хосе Ортіса (2021). Сьогодні можна знайти в Інтернеті безліч оголошень про курси, підвищення кваліфікації, майстер класи, послуги репетиторів-хореографів, наприклад, Закарпатського інституту післядипломної педагогічної освіти, КНЗ «Черкаський ОІПОПП ЧОР» та ін.

В умовах розповсюдження коронавірусної інфекції важливе використання дистанційних освітніх технологій. Одним із основних компонентів віртуального освітнього середовища може стати освітня сторінка у соціальній мережі. Це стосується і хореографічної освіти. Найперспективншою з соціальних мереж в навчанні, на думку дослідників, вважається Instagram, оскільки може забезпечити мультимедійність, інтерактивність, автономність, динамічність. Для успішного навчання он-лайн хореографам особливо необхідно уміти планувати свій день з обліком часу на навчання, мотивувати себе, самостійне виконувати завдання, контролювати свої знання.

Як бачимо, неформальна освітня інфраструктура в Україні активно розбудовується в різних форматах: вона може «вбудовуватися» в систему формальної, доповнювати ії або бути провідником змін для неї. Будь-які конфігурації можливі, коли вони відображають системну національну освітню політику держави іє результатом спільних зусиль недержавного, громадського та приватного секторів. [4]. 


\section{Список використані джерел:}

1. https://e-koncept.ru/2014/64336.htm

2. http://arhiv.acs.si/dokumenti/Memorandum_on_Lifelong_Learning.pdf

3. https://niss.gov.ua/doslidzhennya/gumanitarniy-rozvitok/osvita-protyagomzhittya-svitoviy-dosvid-i-ukrainska-praktika

4. https://niss.gov.ua/doslidzhennya/humanitarnyy-rozvytok/uchastneuryadovykh-orhanizatsiy-u-zberezhenni-kulturnoyi

5. Герц I. Формування умінь і навичок студентів-хореографів як майбутніх викладачів хореографії. Вісник Національної академії керівних кадрів культури і мистецтв. 2017. Вип. 1. С. 100.

6. https://www.google.com/search?q=Актуальні+питання+мистецької+освіт и + та + виховання

7. https://danceacademy.kiev.ua/\%D0\%BF\%D1\%96\%D0\%B4\%D0\%B2\%D0\% B8\%D1\%89\%D0\%B5\%D0\%BD\%D0\%BD\%D1\%8F\%D0\%BA $\%$ D0\%B2\% D0\%B0\%D0\%BB\%D1\%96\%D1\%84\%D1\%96\%D0\%BA\%D0\%B0\%D1\%8 $6 \% \mathrm{D} 1 \% 96 \% \mathrm{D} 1 \% 97 /$ 